\title{
The Impact of Organization Learning Culture, Internal Quality Assurance, Work Culture to Organization Performance and Student Satisfaction as Intervening Variables
}

\author{
Agus Arijanto $^{I}$, Ali Imron ${ }^{2}$, Wiwiek Rabiatul Adawiyah ${ }^{3}$ \\ 1. Lecturer at the Faculty of Economics and Business at the University of Mercu Buana \\ Jakarta and Post-Graduate Student Doctoral Program in Management Science at Jenderal Sudirman \\ University, Purwokerto, Central Java; \\ 2 \\ Postgraduate Student Doctoral Program in Management Science, Jenderal Soedirman \\ University, Central Java / Lecturer STIE ASSHOLEH Pemalang Jawa Tengah \\ Purwokerto \\ 3. Chair of the Management Study Program Master and Senior Lecturer in the Management Science \\ Doctoral Program at Jenderal Soedirman University, Purwokerto, Central Java
}

\section{Abstract}

This study aims to determine the effect of Organization Learning Culture, Internal Quality Assurance (SPMI), Universitas Mercu Buana (UMB) Work Culture and Student Satisfaction as intervening variables on Organization Performance at Mercu Buana University Jakarta. The method used in the study is a quantitative method with questionnaires that are taught to lecturers, education staff and students who are considered representative in this study. Data processed in this study using SmartPLS software. The results of this study indicate that the Organization Learning Culture has a positive effect on Student Satisfaction, Internal Quality Assurance has no positive effect on Student Satisfaction, UMB Work Culture has a positive effect on Student Satisfaction. For variable Organization Leraning Culture, Internal Quality Assurance (SPMI), UMB Work Culture its direct influence is smaller then with intervening variables Student Satisfaction has a positive influence and significance on Organization Performance.

Keywords: Organization Learning Culture, Internal Quality Assurance (SPMI), Work Culture, Student Satisfaction, Organization Performance.

DOI: $10.7176 / \mathrm{IKM} / 9-2-09$

\section{Introduction}

In the millennial era and the current globalization of an organization is increasingly challenging. An organization if you want to exist and be able to compete must always follow the changes that occur by always making continuous improvements to achieve the quality desired by the community. This applies to any organization including an education organization especially higher education or university. So that the ongoing changes with various increasingly difficult challenges will require organizations to continue to learn and improve themselves with good and guaranteed quality, because successful organizations are organizations that are able to learn and continue learning. Therefore, in the learning process must be created as a culture in the organization in such a way that the daily activities and actions of all members will be able to reflect the sustainability of the learning process. If the learning process has become a strong culture, organizational capacity is expected to increase, which will definitely affect organizational performance. The same is explained by Malik, et al., (2011) that "A good Learning Culture will not only help employees to show high levels of performance but also maintain good employees in the organization" the organizational culture as intended is the organizational learning culture. . This is the culture and values held in organizations that support the sustainability of the learning process to develop overall organizational capacity. Organizational learning culture is a form of culture that supports the learning process so that it will acquire, develop and transfer knowledge easily. Knowledge is one of the important intangible assets and has strategic value. With this understanding, universities can use knowledge as a resource in achieving goals. Where that can be achieved only if knowledge is managed well. Knowledge management can be applied as a strategy to achieve organizational success. According to Allamel \& 
Saba (2010) knowledge management can be an added value for organizations by applying knowledge to service organizations.

Based on the background above, this study aims to determine the effect of the influence of Organization Learning Culture, Internal Quality Assurance (SPMI), Work Culture and Student Satisfaction as intervening variables on Organization Performance. Knowledge management within organizations has been investigated by Allamel \& Saba (2010) conducted in case studies of selected sub-companies from the city of companies in Esfahan. Research that is very rare and realistic is still little about Organizational Performace in Higher Education Institutions or often called Higher Education Institutions (HEIs). In this study the method used is a quantitative method that uses Partial Least Square (PLS) and where there are no studies that discuss the same topic in the college.

With the increasing demand for higher education which leads to exponential growth in student enrollment. So that when the government has limited capacity to finance good public institutions, the government encourages private sector participation in the formation of various higher education in accordance with the 1945 Constitution, namely to educate the life of the nation. With this rapid expansion, concerns about the quality of education of HEIs in SSA (Kara et al., 2016). The choice of institutions with better and better quality of learning has become an important problem for the community and especially prospective students. Therefore Higher Education Institutions are encouraged to be able to satisfy their customers, especially students (Abdullah, 2006).

Among all HEIs customers, students have been identified as the main customers (Pereira and Da Silva, 2003; Abdullah, 2006). This was explained by Kara et al. (2016) say that by making major customers, the results of student perceptions of quality services are relevant to the continuous improvement of HEIs. Student satisfaction is increasingly important for higher education institutions throughout the world. This is related to the quality of academic service delivery (Rouf et al., 2016). By identifying students as primary customers, HEI is thus obliged to operate under market forces efficiently and competitively to satisfy them (Bunce et al., 2016). According to Rouf et al. (2016), the long-term survival of higher education institutions lies in providing quality services.

Student satisfaction has a direct influence on the loyalty they (students) continually commit to HEI (Le Roux and Van Rensburg, 2014). According to Oliver (1999), loyalty involves an attitude dimension that describes repurchase behavior as well as consistent compliance with the product / service for the future. de Marcedo Bergamo et al. (2011) noted the convergence between loyalty, loyalty and retention where loyalty is described as purchasing non-random services over a period of time. In view of Jamal (2006); however, retention is the institution's ability to retain customers that have been obtained / consumers. The desire of students to repursue other academic programs and / or return to working with institutions after graduation results in their retention by HEIs. Loyalty, therefore, culminates in long-term retention and profitability for HEIs (Petre et al., 2006).

Experts argue that for HEIs to attract and maintain student loyalty, institutions must work to improve their services and invest in building strong relationships with students (Ndubisi, 2007; Usman and Mokhtar, 2016). According to Alrousan and Abuamoud (2013), HEIs require additional traditional strategies to attract more new students, retain existing students and build relationships with them. Effectively, satisfaction is a 
mandatory prerequisite for student loyalty and retention (Guo et al., 2012) and they must be the most important goals for all future seeking HEI (Usman and Mokhtar, 2016).

\section{B. Theory Study}

The stakeholders in the higher education sector are parents, students, private sector / government, government, management of higher education institutions, staff from institutions, among others. All of these stakeholders have different conceptions of quality at higher education institutions (Cullen et al., 2003). In Nicholson's view (2011), various education stakeholder groups conceptualized quality and what were more controversial indicators. However, many of those who study quality problems in higher education see from a service quality perspective and from the students' point of view even though this is not without debate about how to measure service quality (Ibrahim et al., 2012). In response to increasing interest in measuring service quality, efforts have been made to measure service quality through proposals and the use of several measurement instruments and this includes but is not limited to Service Quality (SERVQUAL) (Parasuraman et al., 1991), Service Performance (SERVPERF) (Cronin and Taylor, 1994), Higher Education Performance (HEdPERF) (Abdullah, 2006), Quality of Education (EDUQUAL) (Mahapatra and Khan, 2007), Quality Measurement Services in Higher Education Institutions (sqm -HEI) (Senthilkumar and Arulraj, 2011) and Office of Education (EDUSERVE) (Ramseook-Munhurrun et al., 2010), among others.

\section{Organization Learning Culture}

Learning organizations facilitate learning and knowledge formation which are seen as important strategies in improving organizational performance to make organizations stay competitive (Davis, 2008). Companies that carry out leadership styles will have an impact on the learning organization itself (Sahaya,2012). Learning Organization is an effort in order to improve company performance (Weldy, 2009). In addition, according to Banker and Sinkula (1999), Learning organizations are also a necessity to maximize company performance.

Quality management is generally recognized as an approach to organizational management that results in improved performance (Frank,2009). According to Muhammad (2012), the reason for the importance of quality management is that in a growing business competition, demand from customers is increasing, making the organization more focused on quality. Therefore managers and decision makers in organizations need to improve their quality so they can overcome business development.

\section{Internal Quality Assurance System (SPMI)}

Higher education is a part of the national education system that has a strategic role in educating the nation's life and advancing science and technology. The strategic role of higher education continues to pay attention to and apply the values of humanities and the empowerment of a sustainable Indonesian nation. Higher education also has a role in increasing the nation's competitiveness in facing globalization in all fields. Therefore higher education is needed that is able to develop science and technology and produce intellectuals, scientists, and/or professionals who are cultured and creative, tolerant, democratic, strong character, and dare to defend the truth for the benefit of the nation. 
Higher education quality assurance is the process of planning, fulfilling, controlling and developing higher education standards consistently and continuously, so that stakeholders (internal stakeholders) and external universities, namely students, lecturers, employees, the community, business world, associates profession ation, the government can obtain satisfaction with performance and higher education output. This quality assurance activity is an embodiment of accountability and transparency in the management of universities. In accordance with Law Number 12 of 2012 concerning Higher Education, the Higher Education Quality Assurance System (SPMPT) consists of the Internal Quality Assurance System (SPMI) and the External Quality Management System (SPME). SPMI is developed by the relevant university, while SPME is conducted through accreditation. The Internal Quality Assurance System (SPMI) in a tertiary institution is an independent activity from the relevant tertiary institution so that the process is designed, implemented and controlled by the relevant university without interference from the government. The government makes guidance in the implementation of the university's internal quality assurance system (SPMI) which aims to provide inspiration about various aspects which are generally contained in SPMI in a university. This is done because each college has different specifications, in terms of history, vision and mission, organizational culture, organizational size, structure, resources, and leadership patterns. In order for universities to always be able to meet the demands of stakeholders' needs that continue to grow, SPMI must also be adjusted to these developments in a continuous (continuous improvement) manner.

Universitas Mercu Buana Jakarta has pioneered and developed the concept of the university's internal quality assurance system (SPMI). The concept includes the definition of quality assurance, the implementation cycle of quality assurance, organization, documentation systems, and human resources. SPMI at UMB is carried out by the Quality Assurance Center Unit under the UMB Chancellor. In the implementation of the guarantee system for the provision of education in higher education in accordance with the Guidelines for Quality Assurance (Qua-lity Assurance) of Higher Education (2003, pp. 16-19), several prerequisites are needed, namely: commitment, paradigm change, and the mental attitude of the actors of the higher education process, as well as organizing quality assurance in higher education. The implementation of a quality management system in universities often encounters obstacles / obstacles in the field, among others; awareness of the perpetrators of the education process about the importance of quality assurance as stakeholders' needs are still low, the commitment of the actors of the higher education process to guarantee and improve the quality of education is still lacking, understanding of the concepts and implementation of SPMPT by academicians is not evenly distributed, governance and mechanical guarantee work quality has not been fully developed, the empowerment of human resources, especially lecturers to support the quality assurance system has not been optimal, and the use of information and communication technology to support the internal quality assurance system has not been optimal. And the Mercu Buana University Jakarta is a private university accredited A by BAN-PT in 2016.

\section{Work Culture}

In some literature, according to Sumanto, Herminingsih, "The Effect of Organizational Culture and Work Motivation on Organizational Commitments at PT. bank Central Asia Tbk. Tangerang Main Branch Office, Mercu Buana University Management and Business Journal, Volume 2, Number 1, March 2016, the term corporate culture or corporate culture is often replaced with organizational culture. Koentjaraningrat (2009: 14) 
suggests based on anthropology that "culture is the whole system of ideas, actions and human work in the lives of people that are made into human property by learning". Mangkunegara (2005: 113), concluded that organizational culture is a set or assumption or system of beliefs, values and norms developed in the organization that are used as behaviors for its members to overcome the problem of external adaptation and internal integration. According to Robbins (2006) the characteristics of organizational culture are as follows: 1) Innovation and courage to take risks. The extent to which employees are encouraged to be innovative and take risks. 2) Attention to details. The extent to which employees are expected to carry out precision or precision, analysis and attention to details. 3) Stability. The extent to which organizational activities emphasize the status quo as opposed to growth. 4) Orientation to results. The extent to which management focuses more on the results than the techniques or processes used to achieve these results. 5) Orientation to people. The extent of decisions management considers the effects of these results on the people inside the organization. 6) Orientation to the team. The extent to which work activities are organized on teams rather than individuals. 7) Aggressiveness or aggressiveness.

The extent to which people are aggressive and competitive rather than relaxed.In relation to human empowerment, in order to produce professional and high-integrity employees, a standard reference is imposed by an organization, according to Anwar Ikhsan, 2016, Analysis of the Effect of Organizational Culture and Job Satisfaction on Non-Lecturer Employee Performance at Mercu Buana University Jakarta, Journal Scientific Management and Business of Mercu Buana University, Volume 2, Number 1, March 2016. The standard reference is a culture that systematically guides employees to increase their work commitment for the company. (Moeljono, 2003). This organizational culture will reflect the specifications and character of an organization. The corporate culture belongs to and guidelines for all layers of individuals in an organization in carrying out their duties.

Strong culture and good HR management are tools to compete with competitors in an organization. The results of a strong culture is that culture will improve consistent behavior that can create organizational effectiveness that is influenced by employee performance. But if the culture is not good, then the goal will be in the wrong direction. (Kotter \& Heskett, in Darmawiyanti, 2008). If the culture of an organization does not provide a positive thing for the organization, the results to be achieved or the performance of the organization will be bad, because the corporate culture informs employees about how the employees behave properly. Universitas Mercu Buana (UMB), which was founded 25 years ago, has developed into a fairly advanced tertiary education institution, with 15,000 active year students (BAA, 2010).

The change in organizational culture needs to be socialized to all employees so that it becomes daily work behavior so that the organizational culture becomes a collective awareness that can be beneficial for all parties. However, it is indeed not easy to create a new habit, need encouragement, a simultaneous and continuous effort so that the organizational culture becomes a habit positive ones. Culture of discipline, honesty and responsibility must continue to be improved because there are still employees who do not arrive on time both in terms of work, rest and hours of return, in terms of honesty and accountability still need to With Culture The organization will form Buday Work for all employees who at the institution. So that Mercu Buana University has established a work culture that must be formed and instilled by all leaders and employees, namely : 
1. Honest, that is the harmony between words and actions according to applicable regulations. For lecturers not to do plagiarism and for students not to cheat on the exam. or actions and in accordance with applicable regulations. For lecturers not to do plagiarism and for students not to cheat on the exam.

2. Discipline, namely compliance to respect and implement the applicable provisions. For lecturers and students in the form of not being late in conducting lectures.

3. Responsibility in the form of awareness and willingness to do and bear the risk of work. For lecturers implementing Tri Darma of Higher Education related to the performance of lecturers and for students to collect assignments on time.

4. Creative is the belief and continuous will to improve performance. For lecturers and students always try to find new ways.

5. Local wisdom is to include local culture in completing tasks, responsibilities, and communicating. For lecturers and students dressed in batik according to the time specified and conduct research according to the superiority of locality.

6. Environmentally friendly namely awareness and role as well as maintaining the environment, increasing the efficiency and effectiveness of energy use. For lecturers and students in the form of orderly disposing of garbage, green campus and saving electricity and office stationery.

\section{Student Satisfaction}

Among all kinds of customers from Higher Education Institutions or commonly called Higher Education Institutions (HEIs), Students / students have been identified as primary customers (Pereira and Da Silva, 2003; Abdullah, 2006). Describing this, Kara et al. (2016) said that by becoming a major customer, the results of students, perceptions of the quality of services relevant to continuous improvement - continuously from HEIs. Students' satisfaction has increasingly become important for higher education companies throughout the world. This is related to the quality of academic services (Rouf et al., 2016). By identifying students as primary customers, such HEIs are obliged to operate under market forces to efficiently and competitively satisfy them (Bunce et al., 2016). According to Rouf et al. (2016), the long-term survival of higher education institutions lies in providing quality services. Le Roux and Van Rensburg (2014) concluded that institutions must, therefore, work continuously in attracting, serving and retaining their students. According to Kara et al. (2016), students' perceptions of academic services have become relevant to continuous improvement in institutions. students' input, therefore, more often than not is needed to measure the performance of higher education institutions and also to find ways to improve service quality. This is more important because what is a quality service varies from one HEI to another (Cullen et al., 2003; Nicholson, 2011). Therefore, it is very necessary for institutions to determine from the perspective of their students what is a quality service. Students as customers have hope especially regarding the academic services they receive from HEIs. Students, therefore, are content or satisfied when the products and services they receive meet their expectations (Rouf et al., 2016). Satisfaction, therefore, is a function of expectations and experiences which can then contribute to students' perceptions of HEIs (Abu-Hasan et al., 2008). According to Kara et al. (2016), many factors influence students' satisfaction. These factors may include teacher expertise (Butt and Rehman, 2010), available academic resources such as lecture halls, laboratories, libraries, ICT facilities (Prasad and Jha, 2013), inadequate financing (World 
Bank, 2010), administrative problems (Bolliger and Wasilik, 2009), among others. However, certain authors find that academic facilities, for example, are the most important among these factors (Mansor et al., 2012; Coscun 2014). Students' perceptions result in an open expression of feelings about the services they receive from HEIs. According to Kishore (2012) and Kara et al. (2016), students express the desire to return to their institutions to pursue other academic programs, notify friends about their perceptions of the institution and feel happy about having value for money when they have a positive perception and are satisfied with the service they receive from the institution. The act of communicating their warm feelings about the institution shows the level of excitement in being associated with the institution (Dib and Alnazer, 2013). Student satisfaction has a direct effect on the loyalty of (students) continuous commitment to HEIs (Le Roux and Van Rensburg, 2014). According to Oliver (1999), loyalty involves an attitude dimension that outlines repurchase behavior and consistent compliance with products / services for the future. De Marcedo Bergamo et al. (2011).

\section{Organization Performance}

In general, there are three approaches to assessing organizational performance, namely quantitative assessment, qualitative / judgmental subjective judgments and based on respondents' opinions, and finally, triangulation. Lee and Byounggu (2000) classify performance appraisal into four categories, namely financial measures, intellectual capital, balanced scorecard, and tangible and unreal benefits. Albretch (2011) emphasizes that performance is the extent to which an organization reaches a set of predetermined targets that are unique to its mission. These targets will include objective (numerical) and subjective (valuation) indicators. This means that organizational performance refers to the achievement of the organization from a set of predetermined targets. The target consists of objective and subjective goals. Moreover, Kayu et. al (2001) express their own views on organizational performance by clarifying that it results from the contribution of individuals in organizations, where they say that it is a brief measurement of the quantity and quality of contributions in the form of tasks performed by individuals / groups given to organizations depending on the effort made, ability possessed, and conformity with the opinions of their superiors about the requirements of the task Based on the views of several experts above, it can be concluded that organizational performance is defined as the achievement of an organization that is measured by certain standards in a certain period of time. The conceptual framework of the research is as shown in figure 1 below.

According to the description above the researcher determines the following hypothesis :

- $\quad H 1$ :Organization Learning Culture (X1) influences the Organization Performance.

- H2: Organizational Learning Culture (X1) affects Student Satisfaction.

- $\quad$ H3: Internal Quality Assurance System (SPMI) has an effect on Organization Performance.

- $\quad$ H4: Internal Quality Assurance System (SPMI) has an effect on Organization Performance.

- H5: UMB Work Culture influences Organization Performance.

- H6: UMB Work Culture influences Organization Performance.

- H7: Student Satisfaction (Z) against Organizational Performance 


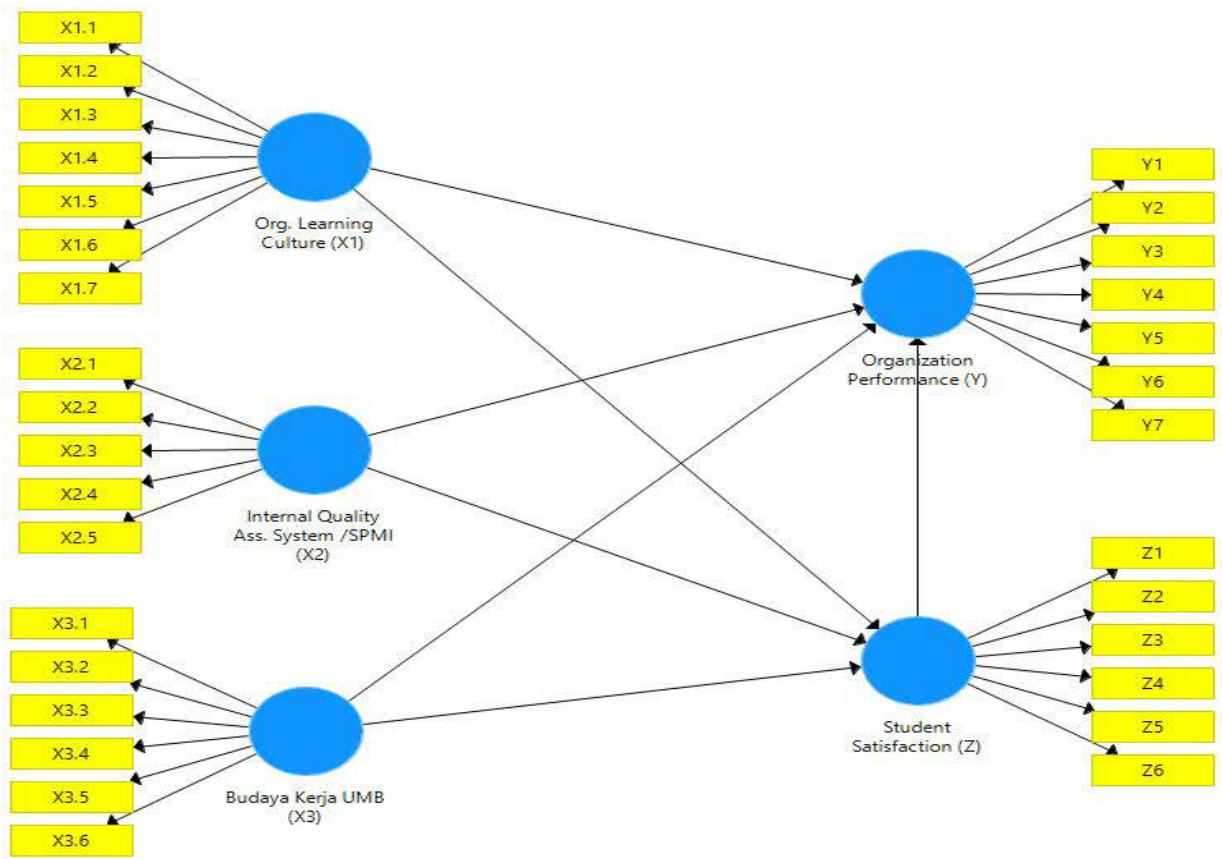

Figure 1. Conceptual Framework

\section{Material and Method}

In general, there are three approaches to measuring organizational performance, namely objective measurement. It has quantitative nature, subjective measurement, has a qualitative / judgmental nature, most often, it is based on the perceptions of the respondent, and the last is Triangulation. Lee and Byounggu (2000) classify four categories of performance measurement, such as financial measures, intellectual capital, balanced scorecard, and benefits that are intangible and unreal. Definition of organizational performance according to Wood et. al (2001) defines that organizational performance is a brief measurement of the quantity and quality of the contributions contributed by individuals / groups to organizations that depend on the efforts made, ability and compatibility from the perspective of superiors about work requirements. Based on the opinions of experts above, it can be concluded that organizational performance is the achievement of an organization that is measured by certain standards in a certain period.

The analysis in this study consisted of 4 Faculties, 4 Postgraduate Programs with A accredited study programs as many as 7 study programs from a total of 24 study programs. Purposive sampling is used to determine the sample, which is a technique of determining the sample with certain considerations, namely a large population, relatively short time and limited funds and so on, so sampling purposive is used by considering the number of samples consisting of 17 deans, 19 chairpersons of study programs accredited A, as many as 24 students from A Study Program, Lecturers and Education Personnel as many as 40 people so that a total of 100 samples. Data collection techniques in this study were conducted through interviews, questionnaires, and observations. The analytical method used to test the research hypothesis is Partial Least Square (PLS) using XLSTAT. 


\section{Results and Discussion}

The results of as many as 100 respondents with purposive sampling as explained above, then tested the validity and reliability obtained as in table 1 below:

Tabel 1. Cosntract Reliability and Validity

\begin{tabular}{clcc}
\hline No. & \multicolumn{1}{c}{ Variabel } & Cronbach's Alpha & rho A \\
\hline 1 & Org.Learning Culture (X1) & 0,895 & 0,929 \\
2 & Internal Quality Ass. (SPMI) - (X2) & 0,721 & 0,748 \\
3 & Budaya Kerja UMB - (X3) & 0,921 & 0,922 \\
4 & Student Satisfaction - (Z) & 0,743 & 0,813 \\
5 & Organizational Performance & 0,704 & 0,770 \\
\hline
\end{tabular}

Referring to table 1 above, that the composite reliability and the cronbach's alpha value meet the expected criteria, which are above 0.6. These results indicate that the model in this study has been reliable. Thus the data can be used to conduct further tests. Furthermore, the Goodness of Fit or Fit Model is performed on smart PLS, which has the purpose of knowing whether a variable can be approached using distribution or not. Here I will describe how to do the Goodness of Fit test using the SPSS program, which is one of the programs used in statistics. By using the SPSS program the Goodness of Fit test can be done quickly and effectively.

Tabel 2. Model FIT (Goodnes of Fit)

\begin{tabular}{lcc}
\hline Decripstion & Satured Model & $\begin{array}{c}\text { Estimulated } \\
\text { Model }\end{array}$ \\
\hline SRMR & 0,832 & 0,832 \\
Chi-Square & 967,929 & 967,929 \\
NFI & 0,515 & 0,515 \\
\hline
\end{tabular}

The SRMR is defined as the difference between the observed correlation and the implied correlation matrix model. Thus, it is possible to assess the magnitude of the average difference between observed and expected correlations as an absolute step (model) fit criteria. Values less than 0.10 or 0.08 (in a more conservative version, see $\mathrm{Hu}$ and Bentler, 1999) are considered suitable. And in table 2 above, the magnitude of the SRMR is 0.132 Henseler et al. (2014) introduced SRMR as a good measure suitable for PLS-SEM which can be used to avoid specification error models. For the interpretation of SRMR bootstrap confidence the results of the hose see the right fit model. NFI is then defined as 1 minus the $\mathrm{Chi}^{2}$ value of the proposed model divided by the $\mathrm{Chi}^{2}{ }^{2}$ alues of the null model. As a result, NFI produces a value between 0 and 1 . The NFI is closer to value 1 , which means better and suitable. NFI values above 0.9 usually represent acceptable or fit.

Tabel 3 . R Square

\begin{tabular}{lcc}
\multicolumn{1}{c}{ Variables } & R Square & R Square Adjusted \\
\hline Organization Performance $(Y)$ & 0,201 & 0,167 \\
Student Satisfaction $(Z)$ & 0,143 & 0,116 \\
\hline
\end{tabular}

In table 3 above the number R Square are variables X1, X2, X3 affect the Organization Performace (Y) R Square of 0.201 or equal to $20.1 \%$ while $79.9 \%$ are influenced by other variables not used in the study. 
Whereas Variables X1, X2, X3 Against Student Satisfaction (Z) are 0.143 or $14.3 \%$ and $85.7 \%$ are influenced by other variables. To find out the total effect of each Organizational Learning Culture (X1) variable, the Internal Quality Assurance System (X2) and UMB Work Culture (X3) on variable Organization Perfomance (Y) through variable intervening Student Satisfaction, bootstrap and get picture 2 as below:

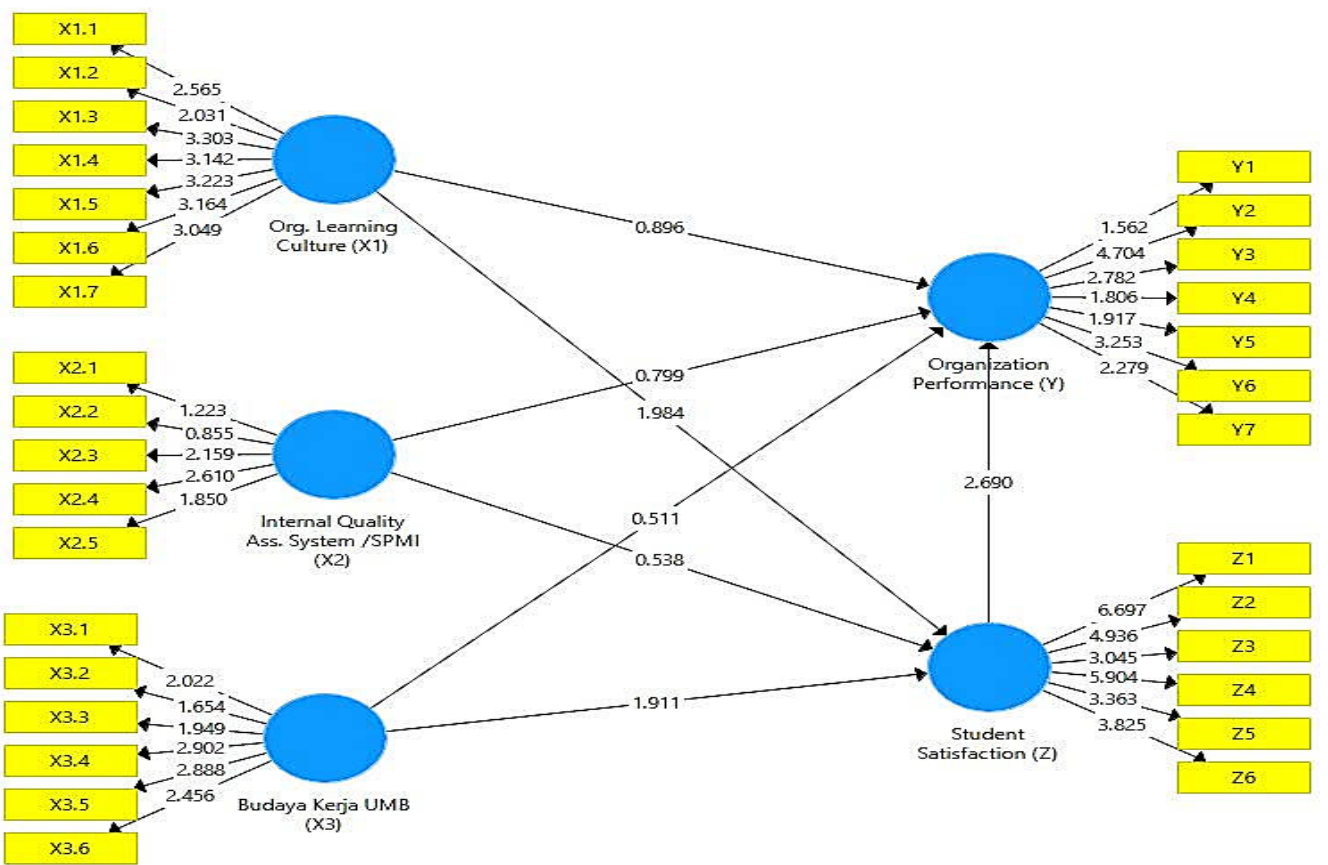

Based on Figure 2 above, Table 4. Total effect can be made which shows the effect of each dependent variable on the independent variable with its intervening variable. The tables are as follows:

Tabel 4. Total Effect

\begin{tabular}{|c|c|c|c|c|}
\hline No. & Variables & $\begin{array}{c}\text { Std. } \\
\text { Deviation }\end{array}$ & T Statistic & P Values \\
\hline 1 & $\begin{array}{l}\text { Budaya Kerja UMB (X3) -> Organizational } \\
\text { Performance (Y) } \\
\text { Budaya Kerja UMB (X3) -> Student Satisfaction }\end{array}$ & 0,152 & 1,235 & 0,218 \\
\hline 2 & $(\mathrm{Z})$ & 0,155 & $\begin{array}{l}1,911 \\
0555\end{array}$ & 0,057 \\
\hline 3 & $\begin{array}{l}\text { Internal Quality Assurance System/ SPMI (X2) -> } \\
\text { Organizational Performance (Y) }\end{array}$ & & & \\
\hline 4 & $\begin{array}{l}\text { Internal Quality Assurance System/ SPMI (X2) -> } \\
\text { Student Satisfaction (Z) }\end{array}$ & 0,204 & 0,538 & 0,591 \\
\hline 5 & $\begin{array}{l}\text { Organizational Learning Culture (X1) -> } \\
\text { Organizational Performance (Y) }\end{array}$ & 0,192 & 1,474 & 0,141 \\
\hline 6 & $\begin{array}{l}\text { Organizational Learning Culture (X1) -. Student } \\
\text { Satisfaction (Z) }\end{array}$ & 0,170 & 1,984 & 0,048 \\
\hline 7 & $\begin{array}{l}\text { Student Satisfaction }(Z) \text {-> Organizational } \\
\text { Performance }(Y)\end{array}$ & 0,138 & 2,690 & 0,007 \\
\hline
\end{tabular}

With the data table above, it can be interpreted that the Total Effect of the variables is as follows: 
a) UMB Work Culture (X3) $t$ count 1.235 is smaller than $t$ table 1.98 so it means that the UMB Work Culture does not have a significant effect on Organization Performance.

b) UMB Work Culture (X3) t count 1.911 is smaller than $t$ table 1.98 so that it means that the UMB Organizational Culture Performance.

c) Internal Quality Assurance System (SPMI) X2 t count 0.555 smaller than t table 1.98 so that the Internal Quality Assurance System (SPMI) X2 does not affect Organization Performance

d) Internal Quality Assurance System (SPMI) X2 with t count 0.538 smaller than t table 1.98 so that the Internal Quality Assurance System (SPMI) X2 does not affect Organization Performance.

e) Learning Culture Organization (X1) with t count 1.474 is smaller than t table 1.98 so that the Organization Learning Culture does not affect Organization Performance.

f) Organizational Learning Culture (X1) with t count of 1.984 is greater than $\mathrm{T}$ table 1.98 so that the Organization Learning Culture has a positive and insignificant effect on Student Satisfaction (Z)

g) Student Satisfaction $(Z)$ with $t$ count of 2.690 is greater than $t$ table 1.98 so Student Satisfaction has a positive positive effect on Organizational Performance (Y).

\section{Conclusion}

According to the study above, then in these institutions the Organization Learning, Internal Quality System, UMB Work Culture does not affect the Organization Performance directly but through the variable intervening Student Satiscfaction the three variables have a positive and insignificant effect on Organizational Performance. This shows that student satisfaction has a large influence on the high performance organization. If high student satisfaction eats Organizational Performance at these educational institutions increases. So that with regard to creating a Learning Organization Culture, building and implementing an Internal Quality Assurance System (SMPI) and creating a UMB Work Culture in ways that are more tangible and easily accepted by all parties will create a high Student Satiscation so that it will impact the Organization Performance of the institution. Higher education is unique as a service experience in that most consumers must meet academic criteria and sometimes strict personal before being allowed to enter experience through a series of assessment assignments, students are assessed based on their suitability as continuing customers "(Rowly, 1997, p. 9) . It is common for Higher Education Institutions (HEIs) to understand that the support provided is in the form of providing functional learning facilities and fostering industrial relations, as well as empathy from management, and fostering a strong emotional bond within students and institutions so that good satisfaction will achieved.

\section{Limitations and future research}

An important input from this research is that it relates to other factors that have not been taken into consideration in this study, and uses more samples to get better data. The time of his research is also regulated longer and prepares proper funds to achieve good and useful research results for all.

\section{Bibliography}

Ahmad Sulaiman, Udik Budi Wibowo, Implementation of Internal Quality Assurance System as an Effort to Improve the Quality of Education at Gajah Mada University, Journal of Educational Management Accountability, Volume 4, No 1, April 2016 
Agbeko, Precious et all, (2018) Indicators of service quality and satisfaction among graduating students of a higher education institution (HEI) in Ghana, Higher Education Evaluation and Development, Emeral Publishing Limited, Vol. 12 No. 1, 2018 pp. 36-52

Anderson, J. C., Rungtusanatham, M., \& Schroeder, R. G. (1994). A theory of quality management underlying the deming management method. Academy of Management.the Academy of Management Review, 19(3), 472.

Avolio, B. J., Bass, B. M., \& Jung, D. I. (1999). Reexamining the components of transformational and transactional leadership using the multifactor leadership questionnaire. Journal of Occupational and Organizational Psychology, 72, 441-462.

Bass, B. M., \& Avolio, B. J. (2004). Multifactor Leadership Questionnaire: Manual and Sampler Set (3rd ed.). Redwood City, CA: Mind Garden

Bass, B.M. \& Riggio, R.E. (2006). Transformational Leadership, Mahwah, New Jersey: Lawrence Erlbaum Associates.

Bass, B. M., \& Avolio, B. J. (1995). Multifactor Leadership Questionnaire. Menlo Park, CA: Mind Garden.

Baker, W. E., \& Sinkula, J. M. (1999). Synergistic effect of market orientation and learning orientation on organizational performance. Journal of the Academy of Marketing Science, 27, 411-27.

Barnett, William P, Greve, Henrich R, \& Park, Douglas. (1994). An Evolutionary Model of Organizational Performance. Strategic Management Journal, 15, 11-28.

Bhimani, A. and Okano, H. (1995, June). Targeting excellence: target cost management at Toyota in the UK. Management Accounting, 73(6), 42-44.

Brush, T. H., Bromiley, P. and Hendrickx, M. (2000, April). The free cash flow hypothesis for sales growth and firm performance. Strategic Management Journal, 21 (4), 455-472.

Cameron and Quinn, (2009) Diagnosing and Changing Organizational Culture: Based on the competing value framework, Addison Wesley Publishing Company, Inc., (Journal)

Daft, (2009)., Management: Management, Issue 6 Book 1, Salemba Empat, Jakarta.

Directorate General of Higher Education, Ministry of National Education. (2004). The 2003-2010 tertiary education (HELTS) long-term strategy towards national policy synergy. Jakarta: Directorate General of Higher Education Ministry of National Education.

Directorate General of Higher Education Ministry of National Education. (2010). College quality assurance system (SPM-PT). Jakarta: Directorate General of Higher Education of the Ministry of National Education.

Hedwig, R. \& Polla, G. (2006). The quality assurance system model and its implementation process in higher education. Yogyakar-ta: Graha Ilmu

Ivancevich, (2001)., Human Resources Management, Issue 8, New York USA, MC Graw Hill Campany Inc., 2001.

John Davies Alex Douglas Jacqueline Douglas, (2007), "The effect of the EFQM Excellence in Model Universities in UK academic culture, Quality Assurance in Education, Vol. 15 Iss 4 pp. 382 - 401

Ministry of National Education. (2009). Permendiknas Number 63, Year 2009, concerning the education quality assurance system.

Luthans, Fred, 2011. Organizational Behavior An Evidence-Based Approach, Twelfth Edition. New York: McGraw-Hill / Irwin.

McKenna, E. and Beech, N. (2004). Human Resource Management, Jakarta: Main Gramedia Library.

Macdonald, J. (2005). Understanding total quality management in a week, Lon-don: St Edmundsbury Press.

Markum, M.E. (2007). Higher education in its historical and development perspective in Indonesia, Jakarta: Director General of Higher Education, Ministry of National Education.

Mishra, S. (2007). In higher education quality assurance: An introduction, Banga-lore, India: National Assessment and Acreditation Council. 